Uşak Üniversitesi Sosyal Bilimler Dergisi

$2014,7 / 3$

\title{
Ahmet Mithat Efendi'nin “Dürdane Hanım” Romanında Türkçe Dersinin Öğretimine Yönelik Öne Çıkan Değerler
}

Mehmet ÖZDEMIR*

Hüseyin TAŞ**

\section{Özet}

Sosyal bilimler alanında değerler üzerine yapılan çalışmalar değerlerin insan davranışlarını açıklamada azımsanamayacak derecede bir öneme sahip olması nedeniyle - son dönemde hız kazanmıştır. Bir toplumun geleceğe güvenle bakabilmesi ve varlığını devam ettirebilmesi sahip olduğu değerleri gelecek nesillere aktarması ile mümkündür. Bu nedenle değerlerin öğretilmesi ve aktarımı toplumsal açıdan büyük önem taşımaktadır. Değerler eğitiminde amaç, toplumun sahip olduğu millî, manevi tüm değerlerin kuşaklar arasındaki aktarımını sağlamaktır. Değerlerin öğretilmesinin ve nesilden nesle aktarımının en etkili şekilde yapıldığı ve yapılabileceği ortam Türkçe dersleridir. Bu derslerde edebi eserler temel materyal olarak kullanılıp bireylere değerlerin aktarımı sağlanabilir. Bu nedenle Türkçe ders kitaplarına alınan metinlerin, bireye olumlu değerleri kazandıracak nitelikte olması gerekmektedir.

$\mathrm{Bu}$ bakış açısıyla araştırmamıza konu ettiğimiz Ahmet Mithat Efendi'nin "Dürdane Hanım" romanındaki değerler doküman analizi yoluyla tespit edilmiş ve bu eserin Türk Milli Eğitiminin Genel Amaçları ile Türkçe dersi öğretim programındaki genel amaçlar başlığı altında verilen değerlerin bireylere aktarılmasında bir materyal olarak kullanılabileceği ortaya konulmuştur.

Anahtar Kelimeler: Değerler Eğitimi, Ahmet Mithat Efendi, Dürdane Hanım Romanı.

\section{The Featured Values for Turkish Course Education in the "Dürdane Hanım" Novel Written by Sir Ahmet Mithat Efendi}

\section{Abstract}

In the social science field, studies for the featured values has gained momentum in recent years to explaining human behavior. Confidently

\footnotetext{
* Yrd. Doç. Dr, Sakarya Üniversitesi, Türkçe Eğitimi Bölümü

** Doktora Öğrencisi, Sakarya Üniversitesi, Türkçe Eğitimi Ana Bilim Dalı
} 
Looking to future and maintaining their existence is possible due to transfer their value to new generation. Therefore, teaching values and transfer are significantly important for their society. Aim of the values education is to provide transfer between generations all national, spiritual values owned by goverrnmental. This is turkish lesson that is teaching values and tranfer it efficiently from generations to generations. İn this lesson, values tranfer can be achieved due to using as basic material for literary Works. Therefore text that is in turkish lesson book is must be qualified for individual possible values.

In this perspective, values that is issue of our study in the "Dürdane Hanım" novel written by sir Ahmet Mithat were identified owing to document analysis method and have been demonstrated that can be used as material for transfer value to individuals given in the turkish lesson under topic of general objectives of the curriculum and The general aims of the Turkish national education.

Key Words: Values Education, Ahmet Mithat Efendi, Dürdane Hanım Novel.

\section{Giriş}

XIX. Yüzyılda Osmanlı Devleti, o eski hayranlık uyandıracak ihtişamını kaybetmiş, askerî gücünden uzaklaşmış, siyasi ve idarî birçok sorunla karşı karşıya kalmıştır. Bu durum karşısında devlet adamları çözüm arayışı içerisine girmişler ve devletin kurumsal yapısında ve sosyal yaşantıda birtakım değişikliklere imza atmışlardır. II. Mahmut ile başlayan bu süreç Tanzimat Fermanı'nın ilânı ile devam etmiştir.

Tanzimat Dönemi, Osmanlı için bir dönüşümün başlangıcı sayılır. "Edebiyattan düşünceye, düşünceden hayat tarzına varıncaya kadar Batı usulüne uygun davranılmaya başlanmış ve kurtuluşun bu modelle gerçekleşeceği fikri gelişmiştir." (Yakıt, 1992: 233). Tanzimat sadece bir batılılaşma hamlesi değil, aynı zamanda hukuki, sosyal, ekonomik ve eğitim alanlarındaki yeniden yapılanmanın da adıdır.

1839 yılında ilan edilen Tanzimat Fermanı'nda eğitimle ilgili herhangi bir madde yoktur. Fakat artık devlet adamları, girişilen yeniliklerin başarıya ulaşabilmesi ve kalıcı olabilmesi için bilgili bir toplum, yeni bir aydın tipi ve kadro oluşturmak gerektiğini biliyorlardı. (Akyüz, 1997: 139).

Tanzimat Fermanında maârifle ilgili köklü tedbirlere yer verilmeyişin, hatta 1845 tarihine kadar bu konuyla yakından 
ilgilenilmemesinin sebeplerini Tanzimatçıların ihmalinde değil, o zamanki muhafazakârların tutumlarında ve siyasi olayların yoğunluk kazanmasında aramak doğru olur (Kodaman, 1988: 9).

Her ne sebeple olursa olsun Tanzimat Fermanı'nda eğitimle ilgili herhangi bir düzenlemeye yer verilmemiş olmasına rağmen bu dönemde eserler kaleme alan başta Ahmet Mithat Efendi olmak üzere birçok şair ve yazar, eserleri vasıtası ile toplumu eğitmeyi ve bilgilendirmeyi amaçlamışlardır. Çünkü edebi ürünlerin eğitici yönü her dönemde toplumların iyiye ve güzele yönlendirilmesinde birer vasıta görevi üstlenmiştir. Bu durumu Cahit Kavcar şöyle ifade eder:

Edebi eserlerin büyük bir bölümü, insanlarn çeşitli bakımlardan eğitmek amacıyla yazılmıştır. Türk edebiyatında Yunus Emre birçok şiirini ve Risaletü'nNushiyye adl eserini, Mevlana Mesnevi'sini, Nabi Hayriyye'sini Namık Kemal tiyatro eserlerinin çoğunu Ahmet Mithat romanların, Tevfik Fikret Halûk'un Defteri ve Şermin adl eserlerini, Mehmet Akif Safahat'm Hüseyin Rahmi romanların ve daha pek çok şair ve yazar, eserlerini hep insanlara nasıl yaşanılması, nelere değer verilmesi gerektiğini öğretmek amacıyla yazmışlardır (Kavcar, 1999: 3).

Tanzimat döneminde özellikle roman, toplumdaki bu değişim sürecini en iyi ve ayrıntılı biçimde ele alan edebiyat türü olarak ön plana çıkmıştır. O dönemin romanları, genellikle eleştirel bir içerikle yazılmış ve aydınların toplumu eğitme çabaları da üslup ve içerik bakımından eserlerine yansımıştır (Özdemir ve Süğümlü, 2014: 1065). Bu dönem sanatçıları arasında özellikle bizim de çalışmamızın konusu olan Ahmet Mithat Efendi, vermiş olduğu eserleri ile toplumu eğitmeyi amaçlaması bakımından öne çıkmaktadır. Bu bakımdan onun edebî hayatının bilinmesinin faydalı olacağını düşüncesindeyiz.

\section{Ahmet Mithat Efendi (1844- 1912)}

Ahmet Mithat Efendi, Tanzimat'tan Meşrutiyet'e kadar süren edebî hayatı boyunca hikâye, roman, tiyatro, anı gibi edebî türlerle, çıkardığı gazete ve dergilerle; felsefe, tarih, coğrafya, din, psikoloji, sosyoloji vb. alanlardaki yazılarıyla döneminin en üretken yazarıdır. Edebî çalışmalarının geniş bir kısmını romana ayıran yazar, edebiyatımızda roman türünün gelişmesinde ve yerleşmesinde önemli katkılarda bulunmuştur.

Ahmet Mithat Efendi, romancı kimliğinin yanında bilim, fen ve edebiyatın hemen her sahasında yazılar yazmış, hayatı boyunca çıkardığı dergi ve gazetelerde yazdıklarından başka iki yüz kadar da kitap yayınlamış bir Tanzimat devri yazarıdır (Albayrak, 2010: 1).

Yazar'ın, 1870'li yıllardan itibaren Kıssadan Hisse ve Letaif-i Rivâyât başlığı altında yayınlamaya başladığı eserlerinin sayısı zaman içerisinde 
nicelik ve nitelik olarak hızlı bir gelişme gösterir. Denilebilir ki; ilk örneklerini Batıdan yapılan tercümelerin oluşturduğu roman ve hikâye türü, Ahmet Mithat Efendi ile birlikte edebiyatımızda adı bilinen ve kabul gören bir tür haline gelmiştir.

Her açıdan içinden çıktığı toplumu reddetmeyip sahip çıkan, ona yeni bir ufuk kazandırarak ileriye taşımayı hedefleyen Ahmet Mithat Efendi, romanlarında bir anlamda Türk halkının hayata bakış açısını, tefekkürünü ve olayları muhakeme edişini aksettirmiştir. Bir Türk gibi hissedip, duyup düşünerek Batılı bir türde eser vermesi henüz tam manasıyla kendisini ifşa edememiş, içine kapalı bir toplumun iç dinamiklerini kaleme alması, o dönemin insanını anlayıp tanımlamamız adına değerli bir çabadır (Yusoğlu, 2011: 292).

Yazarın eserlerindeki bu çabayı Nüket Esen, bizim de katıldığımız şu sözlerle değerlendirir: "Ahmet Midhat'ın birçok eserinden yüzyıl Osmanl kimliğindeki Doğu/Batı ikilemini şiddetle hissettiği meydana çıkar. İçinde büyüdüğü ve yaşadığı medeniyette gördü̈̆̈̈ aksaklıklara çare bulmaya çalışırken bu medeniyeti devaml savunan, ama ayn zamanda Batı medeniyetine duyduğu merak ve hayranlı̆̆l da ortaya koyan bir yazardır. (...) Batı'da hayran olduğu, onu cezbeden bir şeyler vardır; dikkati bir kere Batı'ya yönelmiştir. Ama kendi kültürüne de sahip çıkar. Yalnız artık kendi kültüründe neyi savunmak ihtiyacını duyuyorsa bunu Batı ile karşılaştırarak yapar." (Esen, 2006: 17).

Mustafa Nihat Özön'e göre de Ahmet Mithat'ın yazarlı̆̆ının temelini, Batı romanlarından ödünçlenen teknikleri kullanarak halk hikâye geleneğinden gelen yerli malzemeyi bir meddah tavriyla okura aktarma çabası oluşturmaktadır (Özön, 2009: 230). Ahmet Mithat için sanat, halkı eğitmek için bir araçtır. $\mathrm{O}$, meddahlar gibi okuyucunun dikkatinin eksilmemesine önem verir, öteden beri var olan hikâye anlatma geleneği içinde, her hikâyesinden bir hisse çıkarılması amacı doğrultusunda anlatacaklarını düzenler. (Enginün, 2007: 194). Sosyal fayda pesinde kosan bir yazar olarak Ahmet Mithat'ın hikâye ve romanlarında ulaşmaya çalıştığı hedef, Türk halkında çağdaş medeniyete uymayan düşünce ve yaşayış tarzını değiştirmektir. (Akyüz, 1995: 72).

Ahmet Mithat Efendi, yazdığı eserlerle kendini adeta toplumu eğitmeye adar. Toplumu önce okumaya alıştırmak sonra da onu kültür ve ahlâk bakımından belli bir seviyeye taşımak ister. Madde ve kültür sahalarındaki terakkiyi hürriyet ve rejim meselesinden daha öncelikli gören Ahmet Mithat'ın bu yaklaşımı devrin hükümdarı II. Abdülhamid'le de örtüşmektedir (Okay, 1989: 8). 


\section{İlköğretim İkinci Kademe Türkçe Öğretim Programında Değerler}

Eğitimin temel amaçları içerisinde alan uzmanlarının en fazla üzerinde durduğu konu, çağın gereklerine uygun insan yetiştirmektir. Toplumlar varlıklarını devam ettirme adına çağa uygun insanlara ihtiyaç duymakta ve bu doğrultuda genel kazanımlar adına eğitim programlarını, özelde de öğretim programlarını düzenlemektedirler. Ülkemizde eğitim öğretim faaliyetleri belirli kanunlar çerçevesinde yapılmaktadır. Bu kanunlardan en önemlisi tüm disiplinlerin eğitim programlarının hazırlanmasında da temel alınan 1739 sayılı Milli Eğitim Temel Kanunu'dur. Türk Milli Eğitimi'nin genel amaçları bu kanunda şu şekilde yer almaktadır:

"Atatürk inkulap ve ilkelerine ve Anayasada ifadesini bulan Atatürk milliyetçiliğine bağll; Türk Milletinin milli, ahlaki, insani, manevi ve kültürel değerlerini benimseyen, koruyan ve geliştiren; ailesini, vatanın, milletini seven ve daima yüceltmeye çalışan, insan haklarına ve Anayasanın başlangıcındaki temel ilkelere dayanan demokratik, laik ve sosyal bir hukuk Devleti olan Türkiye Cumhuriyetine karşı görev ve sorumluluklarını bilen ve bunları davranış haline getirmiş yurttaşlar olarak yetiştirmek;

Beden, zihin, ahlak, ruh ve duygu bakımlarından dengeli ve sağglılı şekilde gelişmiş bir kişiliğe ve karaktere, hür ve bilimsel düşünme gücüne, geniş bir dünya görüşüne sahip, insan haklarna saygill, kişilik ve teşebbüse değer veren, topluma karşı sorumluluk duyan; yapıcl, yaratıcı ve verimli kişiler olarak yetiştirmek"; (METK, 1973: 1).

Milli Eğitim Temel Kanunu'ndaki bu amaçlar birtakım değerlerin öğrencilere aktarılmasının eğitimin ana hedefi olduğunu ortaya koymaktadır. 2006 Türkçe Dersi Öğretim Programında (6 - 8.sınıf) ise değer aktarımı ile ilgili ayrı bir başlık yer almamaktadır. Değerlerin öğrencilere aktarılması ile ilgili hedeflere "Genel Amaçlar" bölümünde yer verildiği şu şekilde görülmektedir:

“Dilimizin, millî birlik ve bütünlüğümüzün temel unsurlarından biri olduğunu benimsemeleri,

Türkçeyi, konuşma ve yazma kurallarına uygun bilinçli, doğru ve özenli kullanmaları,

Türk ve dünya kültür ve sanatına ait eserler aracilğglyla millî ve evrensel değerleri tanımaları,

Hoşgörülü, insan haklarına saygıll, yurt ve dünya sorunlarına duyarlı olmaları ve çözümler üretmeleri,

Millî, manevi ve ahlaki değgerlere önem vermeleri ve bu değerlerle ilgili duygu ve düşüncelerini güçlendirmeleri amaçlanmaktadır" (MEB, 2006:.4). 


\section{Araştırmanın Amacı}

Bu çalışmanın amacı Ahmet Mithat Efendi'nin Dürdane Hanım romanında öne çıkan değerleri önce tespit edip ardından bu değerlerden hareketle Türkçe eğitimi alanında yararlanmanın gerekliliğini ortaya koymaktır.

\section{Araştırmanın Önemi}

Sosyal bilimler alanında değerler üzerine yapılan çalışmalar, değerlerin insan davranışlarını açıklamada dikkate değer bir öneme sahip olması yönüyle son dönemde hız kazanmıştır. Değerlerin birçok disiplini ilgilendiren bir konu olması, kavramın farklı şekillerde tanımlanması sonucunu ortaya çıkarmıştır. Bazı araştırmacılar değeri bir şeyin arzu edilebilir veya edilemez olduğu hakkındaki inanç olarak tanımlarken (Dilmaç ve Ekşi, 2007: 22), Bazı araştırmacılara göre de değerler ve inançlar, hayatın anlaşılıp yorumlanmasına ve davranışların şekillenmesine rehberlik eder. Böylece insanlar, hayata ve olaylara karşı bir bakış açısı geliştirmiş olur (Akıncı, 2005: 8).

Değerlerin bireyde oluşturduğu bu bakış açısı tüm disiplinlerde olduğu gibi Türkçe eğitimi alanında da değerlerin ele alınmasını gerekli kılmıştır. Türkçe eğitimi alanında dilin estetik yönünü ortaya koyan edebi eserlerin bünyesinde barındırdığı değerler açısından tahlil edilmesi ve bu doğrultuda edebi metinlerin bir ders materyali olarak kullanılması çok önemlidir.

"Edebî eser, okuyucunun yüreğine, zihnine - hiç hissettirmeden; onu yormadan, üzmeden örseleyip zedelemeden - akıvererek ona yeni duygular, hayaller ve düşünceler kazandırır. Onun zevklerini inceltir, duyguların yumuşatır. Ona insanlığın hatırlatır, insan olmanın sorumluluğunu öğretir. Ĕ̆itimin de yapmak istediği bu değil midir?"(Aydemir, 1989: 57). Bu bakış açısıyla Dürdane Hanım romanı ele aldığı değerler açısından çalışmamıza konu edilmiştir.

\section{Araştırmanın Yöntemi}

Çalışmada nitel araştırma yöntemlerinden doküman analizi yöntemi kullanılmıştır. Doküman analizi, araştırılması hedeflenen olgu veya olgular hakkında bilgi içeren yazılı materyallerin analizini kapsar (Yıldırım ve Şimşek, 2008: 187). 


\section{Dürdane Hanım Romanı}

Dürdane Hanım romanı ilk olarak "Tercüman-1 Hakikat" gazetesinde günlük olarak tefrika edilir ve kitap olarak 1882 yllında yayınlanır. Araştırmacılar tarafından (Tanpınar, 2003; Okay, 1989) olay kurgusu, şahıs kadrosu ve ele aldığı aşk ve adalet duygusu yanında, yeni icat edilmiş telefon cihazından ilk defa bahsetmesi yönüyle dikkat çekilen eser, Fenni - polisiye ya da macera romanı olarak da kabul edilmektedir.

Roman, yazarın "iç içe roman tekniğii"ni ilk defa bu romanda denemesi yönüyle de dikkat çeker.

Dürdâne Hanım'ın kurgu açısından en dikkat çekici yönü; Ahmet Mithat'ın diğer romanlarının aksine, bu metinde olayların, sifır odaklayıma sahip tek bir dışöyküsel anlatıcı tarafından süredizimsel (kronolojik) bir zaman düzenine oturtularak aktarlmamasıdır. Bu metinde; yine sınırsız bakış açısına sahip olmakla birlikte, anlatıcının, sözü, farklı içöyküsel anlatıcılara bıraktığı görülü̈r (Sherıdan Aksoy, 2009: 84).

Roman, kahramanların isimleri ile adlandırılan beş bölümden oluşur. Uzun bir mekân tasviri ile başlayan ve yazar anlatıcının diğer bölümlerden farklı olarak kişilerden çok mekânı tasvir ettiği romanın ilk bölümünün adı "Acem Ali Bey"dir. Romanda ikinci bölüm olan "Ayşe Ebe" de yazar, anlatıcılık görevini kendisi adına bir bölüm ayrılan Ayşe Ebe'ye verir. "Kahraman anlatıcı" Ayşe Ebe, bu bölümde dışarıdan üçüncü bir göz olarak Acem Ali Bey, Çerkes Sohbet ve Dürdane Hanım'ı okuyucuya tanıtır. Bu bölümden yola çıkılarak denilebilir ki olayların akışında rol oynayan kahramanların isimleri roman bölümlerinin adı olmuştur. Bu bölümde gayri meşru çocuğu dünyaya getiren ve bize olaylarla ilgili bilgi veren kişi Ayşe Ebe'dir.

Romanda üçüncü bölüm olarak yer alan "Ulviye Hanım"da ise yazar, okuyucuyu romandaki bütün olayları başlatan Ulviye Hanım ile tanıştırır ve gizli olan her şey anlaşılır olmaya başlar. Bu bölümün en önemli özelliği Tanzimat dönemi kadınının iki farklı karakterde - Ulviye Hanım ve Dürdane Hanım - ele alınmasıdır. Ulviye Hanım, hayat tecrübesi olan, okumayı seven güçlü bir kadındır. Dürdane Hanım ise duygusal, aldığı eğitim gereği çok fazla dünyadaki kötülüklerden haberdar olmayan ve yaptığı işlerin sonunu düşünmeyen bir kadın tipidir. Bu bölüm bize ayrıca öz güveni yüksek, eğitimli Ulviye Hanım karakteri ile Dürdane Hanım gibi gerekli ve yeterli eğitim alamamış bir kadın karakterini karşılaştırma fırsatı verir. Ulviye Hanım, hem cinsinin hayatla ilgili eksikliklerinin aslında bir tamamlayıcısıdır. Ayrıca bu bölümde eserin "Fenni Roman" olarak isimlendirilmesinin nedeni olan telefon ile tanışırız. 
Romanın dördüncü bölümü, Dürdane Hanım'ı karşılıksız seven ve olayların akışında etkili olan "Memduh Bey"in ismini almıştır. Bu bölüm bizim romanın ana kahramanlarından olan ve acaba kendisi adına neden bir bölüm oluşturulmamış diye düşündüğümüz Çerkes Sohbet'i tanıdığımız bölümdür. Bu bölümde okuyucu "intikam, ceza ve adalet" kavramları üzerine Çerkes Sohbet'in okuyucuyu şaşırtan yorumları ile düşünmeye başlar. Bu bölümün anlatıcı kişisi ve aynı zamanda olayların gözlemcisi olarak da karşımıza çıkan Çerkes Sohbet'tir. Ayrıca bu bölüm romanın olay akışı, kahramanların duygu ve düşünceleri için okuyucu açısından bir düğüm bölümü olarak da nitelendirilebilir.

Romanın son bölümü diğer bir ifadeyle olayların düğümünün çözüldüğü bölüm olarak da nitelendirebileceğimiz "Dürdane Hanım" isimli bölümdür. Bu bölümde romanın ana kahramanı Dürdane Hanım olay akışındaki düğümü okuyucunun beklentisi dışında bir davranış ile çözer ve "intikam, ceza ve adalet" kavramları alışılmışın dışında okuyucuya aksettirilir. Bu bölümün sonunda Dürdane Hanım, "kendi canına kıyıp karşısındakini yaşatmakla" da insanların cezalandırılabileceğini herkese göstermiş olur. Olayın şahitleri adaletin mahşere kaldığı düşünürler ancak kısa süre sonra Mergub Bey'in başına gelenler adaletin mahşere de kalmadığını gösterir ve eserin son bölümünde bu gerçek şu cümlelerle ifade edilir:

"Bu vak'adan, altı ay sonra ...'da, biçare Mergub Bey henüz on beş günlük güvey iken, aldığg kızın eski bir sevdiği bir âşı̆̆ın yed-i intikamı ile mecrûhen vefat etmiş ve herkes gençliğine ve saadet-i izdivâca doymayan bu biçareye kan ağlamıştı. Pek çok kibâr, cenaze alayında hazır bulundukları gibi, Mısırlı Ulviye Hanım'ın, köle olmak sûretiyle bil-mübâyaa, muahharen nefsini tezevvüc eylemiş olduğu [köle olarak satın alıp sonra da evlendiği] Sohbet Bey dahi cenaze alayında hazırdr. Cenaze, kapıdan çıkarılırken orta yaşlı bir kadının, "Allah taksirâtını afvetsin!" dediğini Sohbet Bey işitince, bu kadının kulağına eğilerek dedi ki: - Gülbeyaz, dava mahşere de kalmadı!" (Ahmet Mithat, 1999: 169).

Buna göre, romanın konusu şöyle özetlenebilir: Annesiyle birlikte İstanbul'da bir yalıda yaşayan genç, güzel, zengin ve iyi eğitimli dul bir kadın olan Ulviye, roman okumayı çok sevmektedir. Okuduğu romanlarla yetinemeyen Ulviye, gerçek bir roman kurgusunun gelişmesine tanık olmak amacıyla komşu yalıda oturan ve genç bir kız olması nedeniyle iyi bir roman kahramanı olacağını düşündüğü Dürdâne Hanım'ı izlemeye başlar. Dürdane Hanım'ın yaşamındaki her şeyden haberdar olmak ister ve iki yalı arasına gizlice bağladığı telefon aracılığıyla, Dürdâne'nin ailesinden habersiz 
ve yalnız dadısı Gülbeyaz'ın bilgisi dâhilinde-zengin bir genç olan Mergub Bey'le gayrimeşru bir ilişki içinde olduğunu ve hamile kaldığını duyar. Telefon vasıtasıyla bu ilişkiyi takip eden Ulviye, Mergub'un Dürdâne'yle evlenmeye yanaşmadığını öğrenir.

Bu yaptığından dolayı Mergub'a kızan Ulviye, bu gence çılgınca aşık olan Dürdâne'ye doğacak çocuğu konusunda yardım etmeye karar verir. Öncelikle Dürdâne'yi nikahı altına almaya yanaşmayan Mergub'la yüz yüze görüşerek onu Dürdane ile evlenmeye ikna etmeye çalışır. Ancak bu yüzleşme sonunda dahi kararını değiştirmeyen Mergub'dan, Dürdâne'nin intikamını almaya karar verir. Bu amaçla erkek kılığına girerek Acem Ali Bey kimliğine bürünür; bu biçimde arkadaşlık kurduğu Çerkes Sohbet'in de yardımıyla Ayşe Ebe'yi kaçırır ve Dürdâne'ye doğumda yardımcı olması için gizlice komşu yalıya götürür. Doğumdan sonra ise, bebeği himayesine alarak Dürdâne'ye yardımını sürdürür.

Dürdâne'yi böylece pek çok sıkıntıdan kurtaran Acem Ali Bey kılığındaki Ulviye, Mergub'tan almayı planladı̆̆ı intikam konusunda Çerkes Sohbet'e danışır. Çerkes Sohbet kendi başından geçenleri anlatarak onun amaçladığı intikamın adalet fikriyle bağdaşmayacağını görüşünü savunur. Bunun üzerine Ulviye araştırma yapmak üzere Sohbet'i Mergub Bey'le görüşmeye gönderir. Çerkes Sohbet'in Mergub'la dostluk kurarak yaptı̆̆ araştırma sonucuna göre; Mergub, ilk başta Dürdâne'yle evlenmeyi düşünür, ancak Dürdâne'nin evlenme konusunda kendisine israr etmemesi üzerine zamanla bu fikirden vazgeçer. Dürdâne'nin önceden nişanlı bulunduğu Memduh Bey'e de kendinden evvel aşk mektupları yazmış olmasını bahane eder ve aynı davranışı evlendikten sonra da sürdürebileceğini ileri sürerek, evlenmek bir yana, doğmuş çocuğuna sahip çıkmayı bile reddeder. Buna karşın, Dürdâne'nin eski nişanlısı Memduh Bey ise, kendisini başkası için terk etmiş olmasına rağmen Dürdâne'yi hâlâ sevmektedir. Dürdâne ya da Mergub Bey'den intikam alma fikrine de asla sıcak bakmamaktadır.

Çerkes Sohbet'in yaptığı bu araştırmanın sonuçlarına dayanarak Ulviye içinde taşıdığı intikam duygusunu sorgular; ancak sonuçta yine de aynı duyguyu Dürdâne'de de oluşturmak amacıyla, bu kez Ulviye olarak Dürdane Hanım'ı yalısında ziyaret eder. Bu ziyarette Dürdâne'ye, baştan beri tüm olayları bildiğini, Acem Ali Bey olarak doğumda kendisine yardım etmiş olan kişinin de kendisi olduğunu ve yüzleştiği Mergub'un sergilediği tavrı bir bir anlatır. Bunun üzerine Dürdâne Hanım, o gece intikam almak için Ulviye'den Mergub'u yalıya getirmelerini ister. Ulviye Çerkes Sohbet'in yardımıyla Mergub Bey'i yalıya götürdüğünde Dürdâne çoktan zehir içmiştir ve ölmek üzeredir. Dürdâne'nin intikamı, Ulviye'nin düşündügünün tersine, Mergub Bey'in öldürülmesiyle değil, yaşamasıyla 
gerçekleşecektir. Mergub Bey, yaşadığı sürece kendisini bu kızın ölümünden sorumlu tutarak manevi azap çekecektir. Ancak romandaki bu adaletsizlik, Dadı Gülbeyaz'in Dürdâne'nin ölümü üzerine söylediği söz üzerine mahşere kalmaz. Kısa bir süre sonra Mergub Bey, yeni evlendiği kızın eski âşığı tarafından öldürülür. Sonunda, en baştan beri gerçek kimliğini bildiği Ulviye ile evlenen Çerkes Sohbet'in, Mergub'un cenazesinde gördüğü Gülbeyaz Dadı`ya, adaletin gerçekten de mahşere kalmadığını söylemesiyle roman biter.

\section{Dürdane Hanım Romanında Öne Çıkan Değerler}

\section{Adil Olma}

Adil kelimesi adalet ve insaf sahibi olan, her zaman hakla hükmeden, hak sahibine hakkını, haksıza ise cezasını veren manasına gelmektedir. Adil her şeyi yerli yerinde yapan, hak ve hukuka büyük bir önemle riayet eden, dürüst ve doğru olan insana denmektedir.

Dürdane Hanım romanı; intikam, ceza ve adalet kavramları üzerine kurulu bir olay örgüsünü içermektedir. Romanın diğer bölümlerinde de bu kavramlar Ulviye Hanım ve Çerkes Sohbet arasında tartışılır. Ulviye Hanım üç dil bilen "eğitimli" bir kadındır. Çerkes Sohbet ise kabadayı ve eski bir katildir. Romanda bu iki kahraman, aynı zamanda yaşanılan olaylar karşısında yargılamayı yapan, hükmü ve cezayı verenlerdir.

Ulviye Hanım, karakterinin tam tersi bir düşünceyi savunarak, intikam duygusu ile çoğu yerde adil davranmaktan uzaklaşmaktadır. Bu intikam ve cezalandırma hissi Ulviye'nin cümlelerine şu şekilde yansımaktadır: " - Bir biçare kızı bu sûretle aldatıp dünyaya bir de çocuk getirdiği hâlde terk eden adama ne ceza tertip eylerdin? Ama düşünmeli ki biçare kızcağız bundan sonra başka bir kocaya varacak olur ise onun yanında yüz aklığı görmek şöyle dursun, ilânihaye bir yüz karalı̆̆ına duçar olacak. İhtimal ki ertesi günü kocası kendisini terk ve tatlik eyleyecek. Hele hiçbir şeyde dahli, kabahati olmayan bir masum çocuk, kendi hayatına bâis olan peder ve vâlide să̆ bulunduklar halde öksüz kalacak. Müddet-i ömründe "piç" diye sâir ebnâ-yı nev'inden birkaç derece alçak addolunacak. Bunların kâffesine sebep olan bir adamın cezasinı sana havale etseler o adam hakkında ne yapardın?" (Ahmet Mithat, 1999: 108).

Ulviye Hanım'ın bu intikam alma hissiyatı karşısında Çerkes Sohbet, aslında kendisinden beklenilmeyecek bir şekilde yaşananları her yönüyle değerlendirmek gerektiğini, yani "adil" olmanın gerekliliğini ifade eden şu cümleler ile Ulviye'ye cevap verir: 
“- Eğer siz gördüğ̈̈nüz ve hikâye eylediğiniz ahvâl, aynen vâki iseler hiç şüphe yok ki Mergub denilen mel'unun cımbız ile etlerini yolarak gebertmeli.

- Benim tahkikâtım neden yanlış olsun? İşler güneş gibi meydanda değil mi?

- Gerçekten güneş bile bazı kere bir bulut arkasında gizlenir de o gün dünya yüzüne hiç güneş doğmamış denilir. Bu misüllü işlerde bir kabahat var mıdır, yok mudur; o kabahat var ise hakikaten hangi taraftadır? Buralarm tahkik etmek pek mühimdir, efendim! Bu tahkik ikmâl olunmadığı surette hiç kabahatsiz bir adamı en büyük cinayetle müttehim etmiş gibi cezalandırmak hiçbir vakitte adalet ve mertlik sayılamayıp, âdeta zulm ve alçaklık addolunur" (Ahmet Mithat, 1999: 108).

Bu sözler karşısında Ulviye Hanım Mergub'a verilecek ceza ile ilgili herkesin kendisi gibi düşüneceği beklentisini kaybeder. Bu noktada Çerkes Sohbet adil olmanın gereği olarak işin her yönüyle araştırılması gerektiğini şu sözlerle eserde dile getirir:

"- Sanki sen Mergub Bey'de kabahat yoktur demek istiyorsun, öyle değil mi?

- Efendim, Mergub mudur, mahbûb mudur her ne ise bu herif her zaman elimizde değil mi? İşi daha güzel tahkik edelim. Her kabahat mahzâ o kabahatin ait olduğu adamdadır zannetmeyiniz. Herkes cinayet işlemekten memnun mu olur? Ne kadar sebepler olabilir ki müttehimleri mazur ve duçar-ı kahr olanları o makhûruna layık gösterir" (Ahmet Mithat, 1999: 122).

Romanın sonunda, adaletin mahşere kalmayıp bu dünyada gerçekleşmesi hadisesiyle, adaletin er geç ortaya çıkacağı vurgulanmış ve bu yolla "adil" olmanın, insan ve toplum hayatında çok önemli bir değer olduğuna dikkat çekilmiştir.

\section{Fedakârlık}

Fedakârlık, insanın çok sevdiği ya da kendisi adına çok önemli gördügü her türlü kıymetten başkası adına vaz geçebilmesidir. Bu durum insanı ahlaki ve sosyal yönden yücelten bir duygu ve değer olarak karşımıza çıkar. Bir toplumda fedakâr insanların sayısı arttıkça, o toplumda birlik ve beraberliğin sağlanması ve toplumun ilerlemesi çok daha hızlı olacaktır. $\mathrm{Bu}$ nedenle bu değer çocuğa çok küçük yaşlarda kazandırılmalıdır.

Dürdane Hanım romanında bu değerin roman kahramanları yoluyla okuyucuya birçok yerde verilmeye çalışıldığını görmekteyiz. Roman içerisinde fedakâr davranışlarıyla karşımıza çıkan kahraman Memduh Bey'dir. Memduh Bey, Dürdane Hanım'ı çok sevmekte ve onun için her türlü fedakârlığı göstermektedir. Onun bu fedakârlığının en önemli ispatı olarak şu ifadesi gösterilebilir:

“-Ah, birader! Dürdane o kadar sevdavî meşrebdir ki sevdiği bir adama iki cihanı feda eder. Ben ise Dürdane'yi öyle bir surette sevdim ki Dürdane'ye, hatta Dürdane'yi dahi feda ederim" (Ahmet Mithat, 1999: 133). 
Dürdane Hanım, yazdığı aşk mektupları ile Memduh Bey'e kendisini sevdiğini söylerken, başka bir kişi ile de aynı duyguları paylaşabilmektedir. Bu durum karşısında bile Memduh Bey, Dürdane Hanım'ı sevmekte ve eline Dürdane Hanım'dan intikam alma fırsatı geçmiş olmasına rağmen bu duygusundan Dürdane Hanım'ın mutluluğu adına vazgeçebilmektedir. Memduh Bey'in bu tavrı romanda şu şekilde yer alır:

“- Ah, birader! Ben sevgili Dürdane'ye hiç fenalık edebilir miyim? Ondan alınacak bir gûne intikam tasavour edebilmek benim için kâbil olur mu? İntikama şâyan bir kimse var ise bu da benim kendimdir. Ben ne kadar şâyân-ı intikam bir habismişim ki Dürdane benden müteneffir oluyor. Dürdane'nin müteneffir olduğu adam bu dünya yüzünde yaşamamalddır, diye kendimi helak edecek oldum. "Senin kendi nefsine hükmün geçmez! diye men eylediler. Hâlâ dahi muhafaza altındayım" (Ahmet Mithat, 1999: 134).

Romanda fedakârlığın en dikkat çekicisini Dürdane Hanım, Mergub Bey karşısında sergilemektedir. Bir taraftan ondan intikam almak istemekte fakat aynı zamanda onu çok sevmektedir. Bunun için ondan intikam almak üzere Mergub Bey'i yalısına getirtir. "Muhabbeti bir rezaletten ibarettir zannedenler, sevdanın ne olduğunu benden öğrensinler" (Ahmet Mithat, 1999: 167) diyen Dürdane Hanım, Mergub Bey'den intikamını onu öldürerek değil, kendi canına kıyarak almayı tercih eder ve Mergub Bey'in sevgisi için kimsenin göze alamayacağı bir fedakârlığı tereddütsüz gerçekleştirir.

\section{Misafirperverlik}

Değerler toplumdan topluma farklılık gösterebildiği gibi bazı toplumlarda da belirli değerler ön plana çıkabilmektedir. Misafirperverlik değeri Türk toplumunun öne çıkan değerlerinden birisidir. Misafirperverlik konuğunu mutlu edecek şekilde ve onu kendi evindeki rahatı aratmayacak şekilde ağırlamak demektir. Bu değer aynı zamanda bireye paylaşmayı ve fedakârlıkta bulunmayı da öğretir.

Dürdane Hanım romanında bu değerin Türk toplumundaki yansımalarını her yönüyle görmemiz mümkündür. Ulviye Hanım, Dürdane Hanım'ı ziyaret etmeden önce müsait olup olmadıklarını öğrenmek ve misafir olacaklarını haber vermek üzere önceden bir haber gönderir ve bu durum eserde şu şekilde yer alır:

“...Ulviye Hanım, gayet sade ve fakat pek yakışıkl bir suretle giyinip kuşanarak Dürdane Hanım'ı ziyarete gitmeye hazırlandı. Fakat gitmezden evvel kendi kethüda kadının Dürdane Hanım'ın yalısına gönderip o gün hanımları 
orada bulunup bulunmadıkların ve Ulviye Hanım'ın bir lâhzacık görüşmeye geleceğini sordurdu ve anlattırdı" (Ahmet Mithat, 1999: 140).

Dürdâne Hanım, romanda konuğu Ulviye Hanım'ı kendi yalısında ağırlar. Onun hâl ve hatırını sorduktan sonra çeşitli ikramlarda bulunur. Ancak ikram edilen kahvenin yanında yer alan "sigara" çocuklar için olumsuz bir tercih olarak dikkat çekmektedir.

\section{Dostluk}

Dostluk, içinde birden fazla değeri barındıran bir yapıya sahiptir. Dostluk, paylaşmak demektir. Acılarını, üzüntülerini, mutluluğunu, sevdiklerini, düşüncelerini, paranı, eşyanı, hiç düşünmeden vermek demektir. Dostluk, güvenmektir, kadirşinaslıktır. Bunun için bu değerin bireye kazandırılması ve dost olan insanların toplum içerisinde fazlasıyla yer alması o toplumdaki birçok istenilmeyen, insanları üzen durumların önüne geçilmesine vesile olacaktır.

Dürdane Hanım romanında dostluk değeri karşımıza ilk olarak Ulviye Hanım'ın, Acem Ali Bey olarak Çerkes Sohbet ile paylaştığı anlarda karşımıza çıkar. Çerkes Sohbet, Acem Ali Bey'i kendisine güven duyduğu ve kendisi için her şeyi yapabileceği bir dost olarak görür. Bu durum romana şu cümlelerle yansır:

“ - Can çıkar da sır çıkmaz. Vâkıa sizinle topu bir kaç defa görüştük. Onlar da pek sathî olduysa da size o kadar muhabbet ettim ki kırk yıllık dostunuz arkadaşını gibi oldum.

Filvâki Çerkes Sohbet bu sözü söylemekle beraber Acem Ali'nin yüzüne öyle bir bakış baktı ki kırk yıllık dostunu değil ama sanki kâlu belâdan beri âşıkıymış gibi bir bakıştı" (Ahmet Mithat, 1999: 15).

Eserde dostluk değerinin yer aldığı bir diğer bölüm ise Dürdane Hanım ile Ulviye Hanım arasında yaşanılanların anlatıldığı bölümdür. Ulviye Hanım, bir eğlence olarak başladığı Dürdane Hanım'ı takip etme işinde zamanla onun her anında yanında olan bir dost kimliği kazanır. Dürdane Hanım da bu dostluğun farkındadır ve bu durumu romanda şu cümlelerle ifade eder:

“Dürdane'nin hâli daha ziyade başkalaştı. Ulviye'nin yüzüne gayet dikkatli bir bakış ile baktıktan sonra gözlerinden bir ateş firlayarak dedi ki:

- Tanıdım efendim, tanıdım! Hakikat, bana herkesten ziyade dost olduğunuzu teslim ederem. Dünyada sizin bana ettiğiniz inâyeti hiç bir kimse, hiç bir kimseye edemez! (Ahmet Mithat, 1999: 142).

Dürdane Hanım, Ulviye Hanım'ı kendisine bir dost görmenin yanında ona güven de duymaktadır. Bu durum eserde yazar anlatıcı 
tarafından, henüz ilk defa görüşen bu iki kadının, "kırk yıllık sırdaş" gibi birbirlerine yakınlaştıkları ifade edilir.

\section{Yardımseverlik}

Yardımseverlik ihtiyaç duyana hiçbir karşılık ya da kişisel menfaat beklemeden gönüllü olarak maddi ve manevi destekte bulunmaktır. Bu değer, sahip olunan imkânların paylaşılması gerektiğine ve tüm insanların faydasına olduğunda değerli olduğuna inanan insanların sergileyeceği bir davranıştır. Çünkü insan yardımseverliğin bir gereği olarak, sahip olduğu gücü ve zenginlikleri başkalarının iyiliği için paylaşır. Bu değer ayrıca insanda var olan bencilliği ortadan kaldırması bakımından da önemlidir.

Dürdane Hanım romanının olay akışı içerisinde yardımseverlik duygusu önemli bir yer tutar. Sadece yeni yazacağı romanına bir malzeme, bir kahraman bulmak adına Dürdane Hanım'ı takip eden Ulviye Hanım, onun içinde bulunduğu zor durumu öğrendikten sonra ona yardım etmeye karar verir. Romanda ilk olarak Dürdane Hanım'ın gizlice doğum yapmasına yardım etmek üzere Ayşe Ebe'yi kaçırır ve onu Dürdane Hanım'ın yalısına getirir. Yalıya ulaştıklarında kapıyı açtırmak adına Ulviye Hanım'ın söylediği şu sözler onun yardımseverliğini ortaya koymaktadır:

"Bir hafta mukaddem Dürdâne Hantm'la yine bu odada ikiniz konuştuğunuz zaman nasıl olup da bir ebe bulabileceğinizi ve sonra çocuğu nerede saklayacağınızı bir türlü kararlaştıramayarak nihayet ikiniz dahi karşı karşıya ağlamaya başladığınızı görüp ve işidip size merhamet eden bir dostunuzum! Artık şüpheniz kalmadı ya! Kapıyı açını efendim!" (Ahmet Mithat, 1999: 45).

Ulviye Hanım, yaşadıkları karşısında Dürdane Hanım'a her an yardım etmek için bir çaba içerisindedir. Dürdane Hanım'ın Mergub Bey'den intikam alma sürecindeki en büyük yardımcısı ve destekçisi Ulviye Hanım'dır. Diğer bir ifadeyle aslında hoş karşılanacak bir duygu olmayan intikam alma sürecinde bile Ulviye Hanım, onun yanındadır:

“ - Şimdi, demek oluyor ki böyle bir gaddardan intikama artık karar verdiniz?

- Evet! Hem de istediğim gibi bir intikama karar verdim ki onu dahi mücerred sizin muavenetinizden beklerim.

- Elimden her ne gelir ise diriğ etmeyeceğgimden emin olunuz. Bu intikam, kendi intikamim olmaktan ziyade bana lezzet veriyor" (Ahmet Mithat, 1999: 151).

Ulviye Hanım'ın roman içerisinde Acem Ali Bey olarak giriştiği her işte en büyük yardımcısı Çerkes Sohbet'tir. Çerkes Sohbet hem iyi bir 
dost hem de Ulviye Hanım'ın en büyük destekçisidir. Birçok işte de Acem Ali Bey'e körü körüne itaat etmektedir.

\section{Azimli Olmak}

Azim, insanın amacı için zorlukları göze alması ve onları ortadan kaldırma konusundaki kararlılığıdır. Azim, irade ve kararlılık daima birliktedir. Azim ve irade isteğimizin gücüne bağlıdır. Azimli kişi herhangi bir engelle karşılaştığında hemen o işten vazgeçmez. Tam aksine büyük bir istekle olayların üzerine gider ve engelleri aşar. Azimli olan insanlar hayatta daima başarılı olurlar.

Eserde azimli bir birey olarak karşımıza çıkan kahraman Ulviye Hanım'dır. Ulviye Hanım ulaşmak istediği hedefler için sabırla çalışmaktadır. Onun bu azimli duruşunu ilk olarak Dürdane Hanım'ın gizli sırlarını öğrenmek için verdiği uğraşta görürüz. Yazar anlatıcı, Ulviye Hanım'daki bu azmi; " Bu merakı ile Ulviye Hanım'ın göze aldırdığ tehlikeleri burada müfredâtı veçhile saymaya lüzum görmeyiz. Vakıa, bu yoldaki vukuât içinde ezcümle bir gün yekdiğgeriyle kavga etmekte bulunan sekiz, on kadar kayıkçı ve mavnacıların içine saldırmak ve birkaç yumruk ve tokat kendisi yediği gibi birçoklarım da kendisi vurmak gibi mühim şeyler dahi var..." (Ahmet Mithat, 1999: 71) cümleleriyle ifade eder.

Yazar eserin bir başka bölümünde Ulviye Hanım'daki merakla birlikte gördüğü azmi şöyle dile getirir: "İnsan bir şeyi emel eylediği zaman suûbet denilen mâni, o sâhib-i emeli asla meyus edemez." Yazar bazı büyük hapishanelerdeki müebbet hapis cezasına çarptırılan mahkûmların, firar etmek için tünel kazmaları esnasında gösterdikleri büyük sabır ve azme dikkat çeker (Ahmet Mithat, 1999: 77).

Romanda Ulviye Hanım'ın bu azmi, onun tam zıddı bir karaktere sahip Dürdane Hanım karakteri ile ön plana çıkartılmıştır. Yukarıda da ele aldığımız örneklerden hareketle, azimli ve kararlı olmanın yazar tarafından eserde vurgulandığını söylemek mümkündür.

\section{Sonuç}

Bir toplumun geleceğe güvenle bakabilmesi ve varlığını devam ettirebilmesi sahip olduğu değerleri gelecek nesillere aktarması ile mümkündür. $\mathrm{Bu}$ nedenle değerler eğitimi toplumsal açıdan büyük önem taşımaktadır. Değerler eğitiminde amaç, toplumun sahip olduğu milli, manevi ve evrensel tüm değerlerin kuşaklar arasındaki aktarımını sağlamaktır. Değerlerin öğretilmesinin ve nesilden nesle aktarımının en etkili şekilde yapıldığı ve yapılabileceği ortam Türkçe dersleridir. Bu derslerde edebi eserler temel materyal olarak kullanılıp bireylere değerlerin 
aktarımı sağlanabilir. Bu nedenle Türkçe ders kitaplarına alınan metinlerin, bireye olumlu değerleri kazandıracak nitelikte olması gerekmektedir.

$\mathrm{Bu}$ bakış açısıyla araştırmamıza konu ettiğimiz Ahmet Mithat Efendi'nin "Dürdane Hanım" romanının Türk Milli Eğitiminin genel amaçları ile Türkçe dersi öğretim programındaki genel amaçlar başlığı altında verilen, "adil olma, fedakârlık, misafirperverlik, dostluk, yardımseverlik, azimli olmak" gibi değerlerin bireylere aktarılmasında bir materyal olarak kullanıldığı görülmektedir.

Şunu da unutmamak gerekir ki edebi eserlerin bir toplumun değerler birikimini gelecek nesillere aktarabilme görevini yerine getirebilmesi ancak, bu eserlerin okuyucuya ulaşabilmesi ve okunması ile mümkün olacaktır. Bu aşamada eğitim kurumlarının ve ailelerin çocuklara bir okuma programı uygulayarak kitap okumayı "kültür" haline getirmeleri de büyük önem taşımaktadır.

\section{Kaynakça}

AHMET MITTHAT EFENDİ (1999), "Dürdane Hanım", Akçağ Yayınları, Ankara

AKINCI, A. (2005). Hayata anlama vermede dini değerlerin ve din öğretimin rolü. Değerler Eğitimi Dergisi, 3 (9), 7-24.

AKYÜZ, K. (1995) Modern Türk Edebiyatının Ana Çizgileri, İnkılâp Kitabevi, İstanbul,

AKYÜZ, Y. (1997) Türk Eğitim Tarihi, İstanbul Kültür Üniversitesi Yayınları, İstanbul.

ALBAYRAK, L. (2010) “Ahmet Mithat Efendi'nin Eserlerinde Ĕ̆itim ve Çağdaş Eğitim Yaklaşımlan Arasında Bir Karşılaştırma," Atatürk Üniversitesi Sosyal Bilimler Enstitüsü, Yayınlanmamış Doktora Tezi, Erzurum

AYDEMIR, C. (1989) Ömer Seyfettin ve Hikâyelerinde Ĕ̆itim Değerleri, Uludağ Üniversitesi Sosyal Bilimler Enstitüsü Yayınlanmamış Doktora Tezi, Bursa.

DİLMAÇ, B. ve EKŞİ, H. (2007). Değerler eğitimi: Temel tartışmalar ve yaklaşımlar. İlköğretmen Dergisi, 14, Sayfa: 21-29.

ENGINUÜN, İ. (2007) Yeni Türk Edebiyatı Tanzimat'tan Cumhuriyet'e, Dergâh Yayınları, İstanbul

ESEN, N. (2006) "Modern Türk Edebiyatı Üzerine Okumalar, İletişim Yayınları, İstanbul

KAVCAR, C. (1999), Edebiyat ve Eğitim, Engin Yayınevi, Ankara 
KODAMAN, B. (1988), Abdülhamit Devri Eğitim Sistemi, Türk Tarih Kurumu Basımevi, Ankara

MEB (2006). İlkoğretim Türkçe Dersi Öğretim programı (6, 7, 8. simflar). MEB Yayınları. Ankara

METK (1973), 1739 Sayılı Milli Eğitim Temel Kanunu, Ankara

OKAY, O. (1989). Batı Medeniyeti Karşısında Ahmet Mithat Efendi, MEB Yayınları, Ankara

ÖZÖN, M. N. (2009) “Türkçede Roman" İletişim Yayınları, İstanbul

ÖZDEMIR, M. ve SÜĞÜMLÜ, Ü. (2014), Ahmet Mithat Efendi'nin "Jöntürk" Romanında Medeniyet Algisı" Turkish Studies - International Periodical For The Languages, Literature and History of Turkish or Turkic Volume 9/3 Winter, Sayfa, 1061-1084

SHERIDAN AKSOY, R. A. (2009), Ahmet Mithat Efendi Romanlarinda Metinsel Kararsızlık, Bilkent Üniversitesi Ekonomi ve Sosyal Bilimler Enstitüsü, Yayınlanmamış Yüksek Lisans Tezi, Ankara

TANPINAR, A. H., (2003) “XIX. Asır Türk Edebiyatı," Çağlayan Kitabevi, İstanbul

YAKIT, İ., (1992), Türk-İslam Kültüründe Ebced Hesabı ve Tarih Düşürme, Ötüken Yayınevi, İstanbul

YILDIRIM, A. ve ŞİMŞEK, H. (2008). Sosyal Bilimlerde Nitel Araştırma Yöntemleri, Nobel Yayınları, Ankara.

YUSOĞLU, N. (2011) "Ahmet Mithat Efendi'nin Macera Romanlarında Intikam" Online Thematic Journal of Turkic Studies, Sayı 2, Sayfa 291-301 